HNO $2020 \cdot 68: 459-460$

https://doi.org/10.1007/s00106-020-00844-x

Published online: 5 March 2020

(c) The Author(s) 2020

T. Rader ${ }^{1,2} \cdot$ A. Bohnert ${ }^{2} \cdot$ C. Matthias ${ }^{3} \cdot$ D. Koutsimpelas ${ }^{3} \cdot$ M-A. Kainz ${ }^{3} \cdot$ S. Strieth ${ }^{3}$

' Department of Otorhinolaryngology - Section of Audiology, Ludwig-Maximilian-University Medical Center, Munich, Germany

${ }^{2}$ Audiological Acoustics Division, Department of Otolaryngology, Head and Neck Surgery, University of Mainz, Mainz, Germany

${ }^{3}$ Department of Otolaryngology, Head and Neck Surgery, University of Mainz, Mainz, Germany

\title{
Erratum to: Hearing preservation in children with electric-acoustic stimulation after cochlear implantation
}

\section{Outcome after electrode insertion with minimal insertion trauma}

\section{Erratum to: \\ HNO 2018}

https://doi.org/10.1007/s00106-0180532-3

The article Hearing preservation in children with electric-acoustic stimulation after cochlear implantation-Outcome after electrode insertion with minimal insertion trauma, written by $\mathrm{T}$. Rader, A. Bohnert, C. Matthias, D. Koutsimpelas, M-A. Kainz, S. Strieth was originally published electronically on the publisher's internet portal (currently SpringerLink) on 21 August 2018 without open access.

With the author(s)' decision to opt for Open Choice the copyright of the article changed on February 2020 to (C) The Author(s) 2020 and the article is forthwith distributed under the terms of the Creative Commons Attribution 4.0 International License (http:// creativecommons.org/licenses/by/4.0/), which permits use, duplication, adaptation, distribution, and reproduction in any medium or format, as long as you give appropriate credit to the original author(s) and the source, provide a link to the Creative Commons license and indicate if changes were made.

The original article has been corrected.

\section{Corresponding address}

\section{Dr. Ing. T. Rader}

Department of Otorhinolaryngology - Section of Audiology, Ludwig-Maximilian-University Medical Center

Marchioninistr. 15, 81377 Munich, Germany tobias.rader@med.uni-muenchen.de

Open Access. This article is licensed under a Creative Commons Attribution 4.0 International License, which permits use, sharing, adaptation, distribution and reproduction in any medium or format, as long as you give appropriate credit to the original author(s) and the source, provide a link to the Creative Commons licence, and indicate if changes were made.

The images or other third party material in this article are included in the article's Creative Commons licence, unless indicated otherwise in a credit line to the material. If material is not included in the article's Creative Commons licence and your intended use is not permitted by statutory regulation or exceeds the permitted use, you will need to obtain permission directly from the copyright holder.

To view a copy of this licence, visit http:// creativecommons.org/licenses/by/4.0/.

The online version of the original article can be found under https://doi.org/10.1007/s00106018-0532-3. 
Hier steht eine Anzeige.

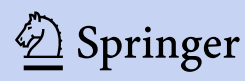

